\title{
Trends in the Use of Tractor Power for Sugarcane Production in Puerto Rico ${ }^{1}$
}

\author{
Lal N. Shukla
}

\begin{abstract}
The types and number of tractors used on a given farm is a fairly reliable indicator of the degree of its mechanization. A field study was conducted to ascertain the trend in the use of tractor power for sugarcane production in Puerto Rico. A total of 957 tractors were included in the study. It was found that there has been a sharp rise in the use of tractor power in sugarcane production in Puerto Rico since 1969 and yearly acquisition of wheel type has been much higher than for tracklayer tractors. Recently acquired tractors average about 100 horsepower per unit.
\end{abstract}

\section{INTRODUCTION}

Industrialization and new farming techniques are the two most important factors inducing mechanization in agriculture all over the world. More agricultural operations are being mechanized in the production of sugarcane with each passing year.

The farm tractor is the most widely used unit on a mechanized farm. It is a versatile power source. The types and number of tractors used on a given farm are fairly reliable indicators of its degree of mechanization.

The rate of mechanization of a crop, or a farm, or the agriculture of a given area, is proportional to the number of tractors used for the crop, farm, or area. This study was conducted for the purpose of determining the trends in the use of tractor power for sugarcane production in Puerto Rico, and thus the trend in the mechanization of field operations in sugarcane production.

\section{MATERIALS AND METHODS}

Farmers, agricultural machinery dealers and government agencies participated in making this study. Private farmers and government agencies supplied information about the tractors currently in use in sugarcane production in Puerto Rico. Make, model, and year of acquisition were re-

1 Manuscript submitted to Editorial Board December 5, 1974.

2 Assistant Agricultural Engineer, Agricultural Experiment Station, Mayagüez Campus, University of Puerto Rico, Río Piedras, P.R. The author expresses appreciation to the personnel of the Sugar Corporation of Puerto Rico, the Agricultural Services Association, the Office of Agricultural Statistics and especially to $\mathrm{Mr}$. Joselo Sánchez Dergan, Assistant Executive Director, Sugar Corporation of Puerto Rico for supplying relevant information. 
corded. Both wheel and tracklayer types were included in the study although no further attempt was made to differentiate between various types of wheel tractors other than on the basis of horsepower rating as shown in table 1.

Appropriate horsepower data of different makes and models was obtained from the Nebraska Tractor Test Data $(1,2,3,4,5,6)$, trade literature $(8,10,11)$, the Green Book $(12,13)$, Power Farming Magazine (9), the

TABLE 1.-Number of wheel type tractors acquired according to F.I.E.I.' horsepower class

\begin{tabular}{ccccc}
\hline \multirow{2}{*}{$\begin{array}{c}\text { Year of } \\
\text { Acquisition }\end{array}$} & \multicolumn{5}{c}{ Tractor horsepower class } \\
\cline { 2 - 5 } & $9-39$ & $40-59$ & $60-99$ & 100 and over \\
\hline 1973 & - & 1 & 57 & 28 \\
1972 & - & - & 73 & 35 \\
1971 & 3 & - & 45 & 35 \\
1970 & 1 & - & 42 & 41 \\
1969 & - & - & 29 & 39 \\
1968 & - & 2 & 6 & 25 \\
1967 & 1 & - & 23 & 13 \\
1966 & - & - & 13 & 9 \\
1965 & - & - & 2 & 4 \\
1964 & - & 2 & 7 & 15 \\
1963 & 1 & 5 & 13 & - \\
1962 & - & 1 & - & - \\
1961 & - & 1 & - & - \\
1960 & - & 6 & - & - \\
1959 & - & 2 & - & - \\
1958 & - & 1 & - & - \\
1957 & - & 21 & 320 & 246 \\
\hline Total & 6 & 4 & 54 & 41 \\
Percent & 1 & & & \\
\hline
\end{tabular}

1 Farm and Industrial Equipment Institute.

Caterpillar Performance Handbook (7), and personal correspondence. For tracklayer tractors, also referred to in the literature as crawler tractors, flywheel horsepower was used in all calculations. The flywheel horsepower is roughly equivalent to belt or brake horsepower commonly found in the literature. In the case of wheel type tractors maximum power take-off (pto) horsepower data was used. In cases where maximum pto horsepower data was not available, some other appropriate power rating was used for the calculation.

The study included some tractors acquired during the late forties and the fifties and it ras difficult to estimate the number. Likely some have 
been discarded already. A tractor life of 13 years was assumed for the purpose of analysis and those acquired during the period 1961 to 1973 were analyzed in detail. As no data was collected after September 1973, it also is likely that the number of tractors acquired during 1973 was higher than reported in the study. The data was analyzed for all wheel and tracklayer tractors acquired every year. Yearly horsepower added to the sugarcane production effort since 1961 in the form of wheel and tracklayer tractors was calculated. Average horsepower per unit data for the wheel and tracklayer tractors were calculated for every year since 1961. Wheel

TABLE 2.-Number of wheel type and tracklayer tractors acquired yearly, their average and total horsepower

\begin{tabular}{|c|c|c|c|c|c|c|}
\hline \multirow[b]{2}{*}{ Year } & \multicolumn{3}{|c|}{ Number } & \multicolumn{3}{|c|}{ Average Horsepower } \\
\hline & $\begin{array}{c}\text { Wheel } \\
\text { type }\end{array}$ & $\begin{array}{l}\text { Track- } \\
\text { layer }\end{array}$ & Total & Wheel type & Tracklayer & Total H.P. \\
\hline $1973^{1}$ & 86 & 26 & 112 & 95.45 & 95.88 & 10702 \\
\hline 1972 & 108 & 37 & 145 & 104.75 & 90.94 & 14679 \\
\hline 1971 & 83 & 13 & 96 & 98.08 & 101.20 & 9456 \\
\hline 1970 & 84 & 11 & 95 & 101.11 & 100.90 & 9605 \\
\hline 1969 & 68 & 21 & 89 & 109.41 & 83.30 & 9192 \\
\hline 1968 & 31 & 19 & 50 & 104.42 & 117.80 & 5475 \\
\hline 1967 & 39 & 26 & 65 & 86.91 & 105.71 & 6140 \\
\hline 1966 & 22 & 22 & 44 & 94.61 & 90.91 & 4081 \\
\hline 1965 & 6 & 21 & 27 & 131.81 & 92.21 & 2728 \\
\hline 1964 & 22 & 15 & 37 & 57.3 & 71.40 & 2332 \\
\hline 1963 & 18 & 45 & 63 & 81.00 & 81.40 & 5121 \\
\hline 1962 & 15 & 19 & 34 & 74.51 & 79.20 & 2622 \\
\hline 1961 & 1 & 16 & 17 & 40.00 & 67.50 & 1120 \\
\hline
\end{tabular}

${ }^{1}$ Incomplete data for 1973.

type tractors also were classified according to the Farm and Industrial Equipment Institute (F.I.E.I.) horsepower classes.

\section{RESULTS AND DISCUSSION}

A detailed analysis was made on 581 of 591 wheel type and 291 of 366 tracklayer tractors. A substantial number of the tracklayer tractors were acquired before 1961. The oldest tractor in the study was a tracklayer acquired in 1948; the oldest wheel type tractor was acquired in 1957. There were 13 different makes and 64 models of the wheel type tractors and 3 different makes and 22 models of the tracklayer type tractors included in the study.

Results of the study are presented in tables 1 and 2. Forty one percent of all the wheel type tractors surveyed had 100 or more horsepower per unit. 
Fifty four percent had anywhere between 60 and 99 horsepower per unit Only five percent were powered with less than 59 horsepower. It seems evident that high horsepower tractors are increasingly prevalent in sugarcane production. For most economical use, these high powered units must be used with due regard to properly matching implements.

The study indicated (table 2) that tracklayer tractors have been used in sugarcane production in Puerto Rico for a long time while those of wheel types are a relatively recent introduction. But one wheel tractor was acquired in 1961 compared with 18 tracklayers. On the long term basis, the number of tracklayer tractors acquired yearly has changed little as shown in table 2. The real upswing in the use of wheel type tractors started in 1967. Only one in 1961, 39 in 1967, and 108 wheel tractors in 1972 were acquired. These now are a major power source for most field and transport operations in sugarcane production.

Table 2 shows the total number of tractors acquired yearly and also compares the number of wheel and tracklayer tractors. The number of the tracklayer tractors acquired yearly to 1966, except 1964, was either higher or equal to wheel type tractors. But the number of wheel type tractors acquired yearly since 1967 has far exceeded the number of the tracklayer tractors. On the long term basis, yearly acquisition of tractors both in terms of total number and horsepower has risen sharply as shown in table 2.

Table 2 also shows the yearly average unit power for both wheel and tracklayer tractors. On the average, wheel type tractors acquired during the last five years (1969-73) had higher engine horsepower than tracklayer tractors. Horsepower per unit for wheel type tractors rose sharply but only moderately for those of the tracklayer type.

\section{CONCLUSIONS}

The following conclusions can be drawn from the data resulting from this study. Both wheel and tracklayer tractors are playing major roles in the mechanization of sugarcane production operations in Puerto Rico. There has been a sharp rise in the use of tractor power in sugarcane production since 1969. Yearly acquisition of wheel type tractors has been much higher in recent years than of tracklayer tractors, both in terms of total number and horsepower. The average recently acquired wheel and tracklayer tractor is about 100 horsepower per unit.

\section{RESUMEN}

Se realizó un estudio para determinar las tendencias en el uso de tractores en la producción azucarera en Puerto Rico, con la participación de varias agencias gubernamentales, concesionarios de maquinaria agricola y agricultores particulares. Se incluyeron en el estudio un total de 591 tractores de ruedas y 366 tractores a oruga, registrándose en cada caso la marca, el modelo y el año de adquisición correspon- 
dientes. En el caso de los tractores a oruga se usaron datos sobre potencia en el volante del motor para todos los cálculos, mientras que en el de los tractores de ruedas se tomó como base la potencia máxima en el eje de toma de fuerza del tractor. Cuando este último dato no estaba disponible se tomó el de máxima potencia en la polea del motor o alguna otra especificación apropiada. Se encontró que se ha registrado un marcado aumento en el uso de tractores en la producción de azucar en Puerto Rico a partir del año 1969. En años más recientes el incremento anual en el número de tractores de ruedas ha sido mucho mayor que el de tractores a oruga tanto en el número de unidades adquiridas como en términos del caballaje por unidad. El promedio del caballaje por unidad para todos los tractores de reciente adquisicion, incluyendo tanto los de rueda como los de oruga, es de alrededor de cien caballos de fuerza.

\section{LITERATURE CITED}

1. Agricultural Engineers Yearbook, American Society of Agricultural Engineers, 8th ed, 394-95, St. Joseph, Michigan, USA, 1961.

2. Agricultural Engineers Yearbook, American Society of Agricultural Engineers, 16th ed, 455-59, St. Joseph, Michigan, USA, 1969.

3. Agricultural Engineers Yearbook, American Society of Agricultural Engineers, 17th ed, 473-77, St. Joseph, Michigan, USA, 1970.

4. Agricultural Engineers Yearbook, American Society of Agricultural Engineers, 18th ed, 481-89, St. Joseph, Michigan, USA, 1971.

5. Agricultural Engineers Yearbook, American Society of Agricultural Engineers, 20th ed, 521-29, St. Joseph, Michigan, USA, 1973.

6. Agricultural Engineers Yearbook, American Society of Agricultural Engineers, 21st ed, 526-33, St. Joseph, Michigan, USA, 1974.

7. Caterpillar Performance Handbook, 2nd ed, 1972.

8. Franklin Equipment Company, Pamphlet Number FA-FK-41, Franklin, Virginia.

9. Power Farming, 51(3): 45-55, Agricultural Press Ltd., London, 1973.

10. Taylor Skidder, Spec. No. S-02-2, Taylor Machine Works, Louisville, Mississippi, USA.

11. Taylor Skidder, Spec. No. S-03-2, Taylor Machine Works, Louisville, Mississippi, USA.

12. The Green Book, 19(40): 65, 66, 82, Norman Kark Publications, London, 1970.

13. The Green Book, 20(42), Directory Publications Ltd., London, 1971. 